\title{
Structure, sequence, and position of the stem-loop in tar determine transcriptional elongation by tat through the HIV-1 long terminal repeat
}

\author{
Mark J. Selby, Eric S. Bain, Paul A. Luciw, and B. Matija Peterlin \\ Howard Hughes Medical Institute, Departments of Medicine and Microbiology and Immunology, University of California, \\ San Francisco, California 94143 USA; Department of Medical Pathology, University of California, Davis, California 95616 USA
}

\begin{abstract}
The human immunodeficiency virus (HIV-1)-encoded trans-activator (tat) increases HIV gene expression and replication. Previously, we demonstrated that tat facilitates elongation of transcription through the HIV-1 long terminal repeat (LTR) and that short transcripts corresponding to prematurely terminated RNA are released and accumulate in the absence of tat. Here, using a transient expression assay, we tested clustered and compensatory mutations, as well as $3^{\prime}$ deletions, in the trans-acting responsive region (tar) and observed that the primary sequence in the loop and secondary structure in the stem of the stem-loop in tar are required for trans-activation by tat. Insertions in the 5' region of tar revealed that tar must be near the site of HIV-1 initiation of transcription for trans-activation by tat. Deletions $\left(3^{\prime}\right)$ and an insertion in tar demonstrated that an intact stem-loop is required for the recovery of prematurely terminated transcripts. Short and full-length transcripts were observed also with HIV type 2 (HIV-2) in the absence and presence of tat, respectively. We conclude that an intact stem-loop in tar is essential for trans-activation by tat and that initiation of transcription by HIV-1 promoter factors and elongation of transcription by tat are coupled.
\end{abstract}

[Key Words: Human immunodeficiency viruses; trans-acting responsive region; trans-activator; transcriptional elongation; RNA structure]

Received October 5, 1988; revised version accepted February 8, 1989.

The human immunodeficiency virus (HIV-1) is the etiologic agent of acquired immune deficiency syndrome (AIDS) (for review, see Ho et al. 1987; Fauci 1988). HIV replication begins after cells are activated and requires the expression of virally encoded trans-activator (tat) (Arya et al. 1985; Sodroski et al. 1985; Cullen 1986; Dayton et al. 1986; Feinberg et al. 1986; Fisher et al. 1986; Peterlin et al. 1986; Wright et al. 1986; Hauber et al. 1987; Kao et al. 1987; Muesing et al. 1987; Feng and Holland 1988; Jakobovits et al. 1988; Rice and Matthews 1988 ) and the regulator of expression of virion proteins (rev) (Feinberg et al. 1986; Sodroski et al. 1986; Malim et al. 1988; Rosen et al. 1988). trans-activations by tat and rev increase the amounts and lengths of HIV-1 transcripts, respectively (Cullen 1986; Peterlin et al. 1986; Hauber et al. 1987; Kao et al. 1987; Muesing et al. 1987; Malim et al. 1988; Rosen et al. 1988). tat and rev are essential for viral replication because deletions of or point mutations in these sequences inactivate HIV-1 (Dayton et al. 1986; Fisher et al. 1986). Although these trans-acting factors have been characterized biochemically and their target cis-acting sequences identified, their precise mechanisms of action remain unknown (for review, see Chen 1986; Varmus 1988).

tat, which is translated from a spliced mRNA, is com- posed of $86-100$ amino acids, depending on the HIV-1 isolate (Muesing et al. 1985; Ratner et al. 1985; SanchezPescador et al. 1985; Wain-Hobson et al. 1985). Localized in the nucleus (Hauber et al. 1987), tat contains a series of cysteine residues followed by a stretch of basic amino acids and forms homodimers in the presence of divalent cations (Frankel et al. 1988). tat acts on the trans-acting responsive region (tar) located between positions -17 to +80 in the $5^{\prime}$ HIV-1 long terminal repeat (LTR) to increase viral gene expression and replication (Rosen et al. 1985).

It was shown recently that tar functions neither as a transcriptional enhancer nor promoter element and that trans-activation is observed only when tar is placed 3 ' to the HIV-1 promoter in its native orientation (Peterlin et al. 1986; Muesing et al. 1987). Jakobovits et al. (1988) reported that sequences from positions +19 to +42 in tar are required for trans-activation by tat. Although transcriptional (Hauber and Cullen 1988; Jakobovits et al. 1988) and post-transcriptional (Cullen 1986; Rosen et al. 1986; Wright et al. 1986) effects of tat have been reported, it is still not understood how and at what level tat interacts with tar.

Previously, we observed that tat has no effect on the rate of initiation of HIV-1 transcription (Kao et al. 1987). 
However, in the absence of tat, elongation of nascent transcripts was blocked, resulting in the accumulation of prematurely terminated transcripts in the cytoplasm of transfected cells. These short transcripts, corresponding to untranslated sequences from positions +1 to +57 , can form a stable stem-loop in solution (Muesing et al. 1987). In the presence of tat, however, full-length HIV-1 transcripts were recovered. To define the primary sequence and secondary structure requirements in tar for trans-activation by tat, we analyzed clustered and compensatory mutations, 3 ' deletions, and $5^{\prime}$ insertions in tar in the presence and absence of tat. Levels of chloramphenicol acetyltransferase (CAT) RNA and protein were measured in cells transfected with HIV-1 LTR-CAT fusion genes (Gorman et al. 1982). We present evidence that tat acts on the predicted stable stem-loop in tar but only when it is placed very close to the site of initiation of HIV-1 transcription. These observations are extended to HIV type 2 (HIV-2), a related human lentivirus that also is associated with AIDS (Clavell et al. 1986; Emerman et al. 1987; Guyader et al. 1987).

\section{Results}

Transient transfection assay to measure trans-activation by tat

Wild-type and all manipulated LTRs of HIV-1 were placed $5^{\prime}$ to the CAT reporter gene (Gorman et al. 1982) in plasmid vectors that contain the SV40 origin of replication and can replicate in COS-7 cells (Gluzman 1981). Constructions in replicating vectors were used because they allowed for higher levels of HIV-1 expression, thus permitting an accurate determination of basal levels of CAT activity and HIV-specific RNA.

\section{Boundaries of tar: $3^{\prime}$ deletions and clustered mutations} in $\operatorname{tar}$

To determine the $3^{\prime}$ border of tar required for trans-activation, we made $3^{\prime}$ deletions in the HIV-1 LTR. A $3^{\prime}$ deletion to position +61 (D1) resulted in wild-type transactivation (Table 1), whereas deletion to position +45 (D2) resulted in a fivefold decreased trans-activation (Table 1). A further deletion of only 3 nucleotides to position +42 (D3) additionally decreased trans-activation twofold (Table 1). Deletions to positions +20 (D4) and +8 (D5) eliminated trans-activation and resulted in three- to fivefold increased basal levels of expression (Table 1). Thus, the $3^{\prime}$ border of tar required for efficient trans-activation lies between positions +45 and +61 .

To define the $5^{\prime}$ and to refine the $3^{\prime}$ borders of tar required for trans-activation, we analyzed clustered mutations in tar, each of which replaced 4 or 5 nucleotides of wild-type sequence with mutant sequence, thereby generating a restriction site (Fig. 1A). The effects on transactivation by clustered mutations from positions -17 to +60 were determined and are presented in Table 1 . Clustered mutations in the region between the promoter and the site of initiation of transcription (M1-M3)
Table 1.

A. CAT assay and free energy values for deletions and clustered mutations in $T A R$

\begin{tabular}{lcccc}
\hline Construction & $\begin{array}{l}\text { Basal } \\
\text { (\% of wt })\end{array}$ & $\begin{array}{l}\text { Fold-TA } \\
(\% \text { of } w t)\end{array}$ & $\begin{array}{l}\Delta G \\
(+1 /+57)\end{array}$ & $\begin{array}{l}\Delta G \\
(+14 /+45)\end{array}$ \\
\hline D1 & 93.7 & 96.9 & -35.3 & -16.5 \\
D2 & 124 & 19.7 & -17.2 & -16.5 \\
D3 & 140 & 9.1 & -15.1 & -8.1 \\
D4 & 310 & 0.85 & & \\
D5 & 490 & 0.81 & & \\
M1 & 75 & 79 & & \\
M2 & 121 & 43 & & \\
M3 & 150 & 122 & & \\
M4 & 78 & 84 & -32.1 & -16.5 \\
M5 & 124 & 68 & -32.2 & -16.5 \\
M6 & 92 & 61 & -29.0 & -16.5 \\
M7 & 85 & 54 & -29.0 & -16.5 \\
M8 & 60 & 14 & -20.7 & -7.8 \\
M9 & 374 & 2.2 & -28.3 & -9.5 \\
M10 & 270 & 2.0 & -35.3 & -16.5 \\
M11 & 190 & 3.7 & -25.9 & -8.8 \\
M12 & 302 & 2.7 & -16.7 & -6.0 \\
M13 & 458 & 49.3 & -28.0 & -12.9 \\
MCl & 250 & 64 & -26.9 & -11.4 \\
MC2 & 110 & 124 & -42.4 & -16.5 \\
\hline
\end{tabular}

B. Fold-trans-activation of HIV-1 and HIV-2 by TAT of HIV-1

\begin{tabular}{lc}
\hline Construction & Fold-TA \\
\hline pHIV-1CATSV & 46.7 \\
pHIV-2CATSV & 68.7
\end{tabular}

(A) Basal and trans-activated (TA) values of CAT activities expressed as percent of wild type (WT) for cotransfections of COS-7 cells with plasmid constructions (column 1) and pSVTATZX or pSVTAT. (D) Deletions; (M) clustered mutations; (MC) compensatory clustered mutations presented in Fig. 1A. pHIV-1CATSV was trans-activated from 54.1- to 74.2-fold. The results represent the average of at least three independent experiments, where the s.E.M. was $<30 \%$. (Columns 4 and 5 ) Calculated free energies $(\Delta \mathrm{G}$ values expressed in $\mathrm{kcal} / \mathrm{mole})$, which were determined according to the method of Zucker and Stiegler (1981). $\Delta \mathrm{G}$ values are presented for sequences from positions +1 and +57 and from positions +14 to +45 . The wildtype free energies are represented by M10 and D1, as their predicted stem-loops are intact. $\Delta G$ values are not presented for D4 and D5, as their stem-loops are eliminated. Because the changed nucleotides in $\mathrm{Ml}, \mathrm{M} 2$, and $\mathrm{M} 3$ are not transcribed, they do not affect the stem-loop in tar. $(B)$ Fold trans-activation (TA) values for transfections of COS-7 cells with pHIV-1CATSV and pHIV-2CATSV with pSVTAT are presented.

yielded high levels of trans-activation. In the transcribed region, clustered mutations from position +1 to +13 (M4-M7) and +46 to +49 (M13) had a small effect on trans-activation. In contrast, clustered mutations from positions +14 to +45 (M8-M12) diminished trans-activation significantly, demonstrating that this region is required for tat action. These sequences correspond to the top half of the predicted stem-loop in tar RNA. Because M8 showed an intermediate phenotype, it is likely that the true $5^{\prime}$ border of $t a r$ is located between positions 
A

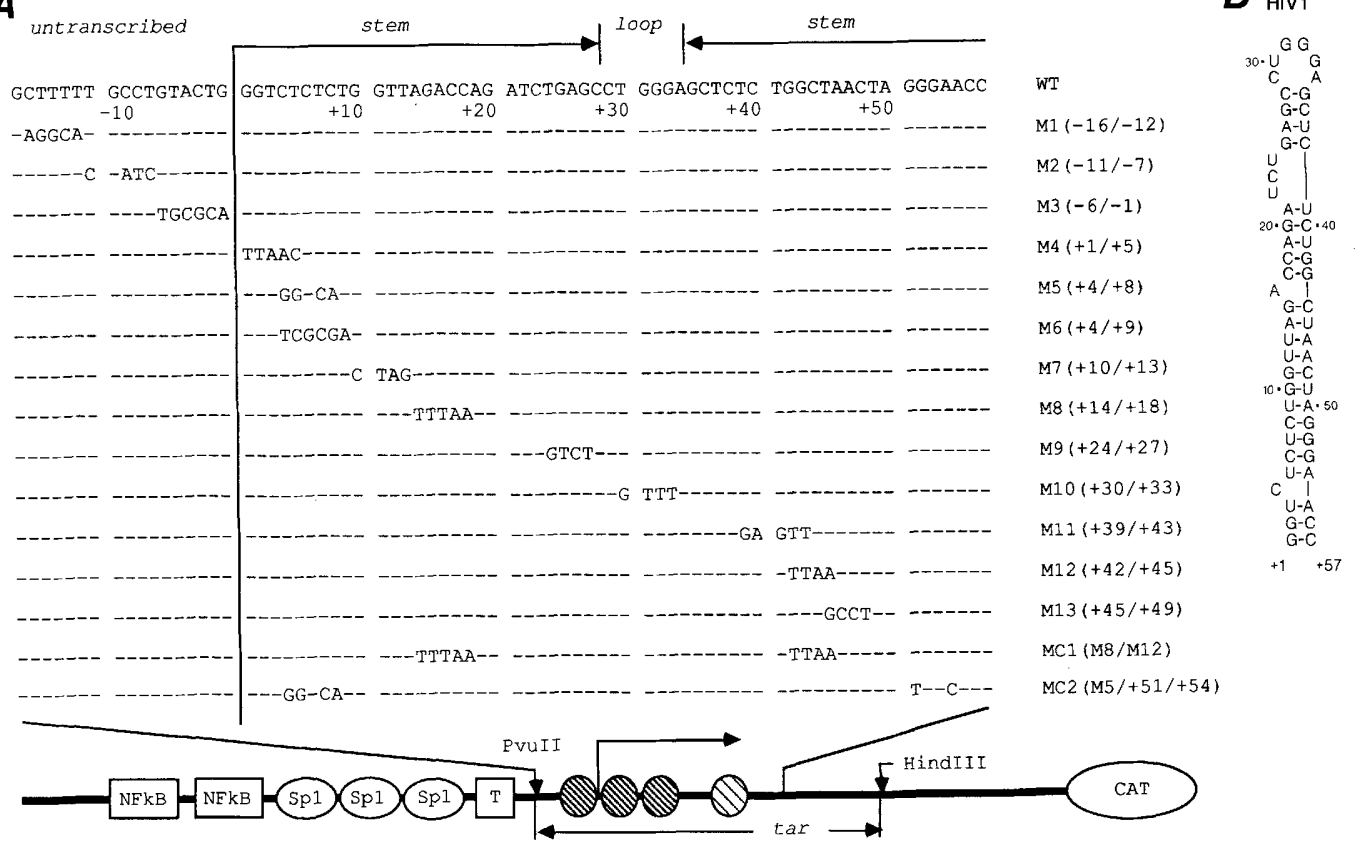

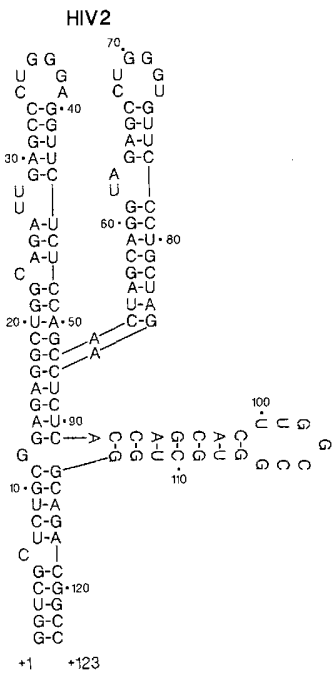

Figure 1. (A) Organization of the HIV-l-LTR and the expanded tar region. The NF- $\mathrm{kB}$ (nuclear factor $\kappa \mathrm{B}$ ) enhancers, Spl-binding sites, and the TATA box (T) are shown. The first three hatched circles represent consensus sequences that bind leader binding protein (LBP) or untranslated binding protein (UBP) in vitro; the fourth hatched circle represents a potential binding site for CTF/NF-1 (CCAAT transcription factor/nuclear factor-1). tar begins at $P_{V u I I}(-17)$ and ends at a HindIII site $(+80)$, which is followed by a polylinker and then the CAT gene. The sequences of the HIV-1 LTR and clustered and compensatory mutations from positions -17 to +57 are displayed. The changed sequences were chosen because they introduce unique restriction sites into the HIV-1 LTR sequence. The changed nucleotides are shown for each mutant below the wild-type sequence. (Right) Constructions and the positions of the changed nucleotides. (Top) Locations of the stem and the loop. $(B)$ Secondary structure representations of the tar regions of HIV-1 and HIV-2. The most stable structures (Zucker and Stiegler 1981) of the tar regions of HIV-1 (left) and HIV-2 (right) are presented.

+14 to +18 . CAT assays from cells transfected with the same constructions in nonreplicating vectors yielded similar patterns of expression (data not shown), validating the use of replicating plasmids. Basal levels of expression for M9-M13, like those for D4 and D5, were from two- to fivefold higher than those for wild-type HIV-1 (Table 1). Thus, we have mapped the most important region of tar required for trans-activation from positions +14 to +45 and identified clustered mutations and deletions that lead to increased basal levels of expression.

\section{Compensatory mutations: investigation of structural features of tar}

To determine the contributions of primary sequence and secondary structure in tar on trans-activation by tat, we analyzed two compensatory mutations that restore base pairing in the predicted stem (Fig. 1A,B). Compensatory mutation $\mathrm{MCl}$, located in the middle of the stem, is a composite of mutations M8 and M12, each of which displayed greatly reduced trans-activation. The ability to trans-activate was recovered mostly with $\mathrm{MCl}$ (Table 1), supporting the notion that secondary structure, but not primary sequence, in the middle of the stem is essential. Because clustered mutations $5^{\prime}$ of position +14 and $3^{\prime}$ of position +45 displayed slightly lower levels of trans-activation than wild-type, we tested a compensatory mu- tation in this region of the stem. MC2, which restored base pairing of M5 at the base of the stem, trans-activated to wild-type levels, suggesting that secondary structure in the lower portion of the stem also contributes to trans-activation. However, the effects of clustered mutations that disrupt base pairing in the middle of the stem have a more significant effect /Table 1).

\section{Stability of the stem-loop in tar}

To define the relationship between trans-activation and predicted RNA stem-loop stabilities, we examined predicted free energies $(\Delta G)$ for the clustered mutations (Zucker and Stiegler 1981). Because tar from positions +14 to +45 is essential for trans-activation, we examined $\Delta G$ values for sequences from positions +14 to +45 and from +1 to +57 (Table 1). For M8-M12, reduced levels of trans-activation are paralleled by decreased predicted stabilities of the stem, especially from positions +14 to +45 (Table 1). The restoration of trans-activation and the corresponding recovery of predicted stability in the stem $(\Delta \mathrm{G})$ by $\mathrm{MCl}$ support this correlation. Because M10, located in the loop, does not alter the stability of the stem yet abolishes trans-activation, the primary sequence of the loop also must be important for trans-activation.

The predicted stabilities of RNA structures that might 
form in transcripts from $3^{\prime}$-deletion templates in tar correlate with trans-activation. Deletions to position +61 (D1) showed wild-type trans-activation and had no effect on the secondary structure of $\operatorname{tar}$ (Table 1). However, deletions to positions +45 (D2) and +42 (D3) demonstrated reduced trans-activations and correspondingly reduced stabilities of the stems. These data indicate that there is a direct relationship between the predicted stability of the stem-loop in tar RNA and trans-activation by tat.

\section{RNA analyses}

Previously, we demonstrated that short transcripts recovered in the cytoplasm reflect premature termination of transcription observed in a nuclear run-on assay of transiently transfected cells and that trans-activation by tat leads to the recovery of full-length HIV-1 RNA (Kao et al. 1987). The high degree of secondary structure in HIV-1 RNA from positions +1 to +57 required careful optimization of hybridization conditions to allow for quantitative detection of these prematurely terminated transcripts. Best conditions for the detection of short transcripts were $200 \mathrm{~mm} \mathrm{NaCl}$ at $37^{\circ} \mathrm{C}$ (Fig. 2). Recovery of full-length RNA was not affected in this range of experimental conditions. Control RNase protection assays using untransfected COS-7 cell RNA showed no protected species (data not shown).

To determine how the clustered and compensatory mutations affect the generation of short and full-length transcripts, we analyzed RNA from cells transfected with these mutant constructions (Fig. 3 and data not shown). In all mutants, we found that changes in the levels of full-length transcripts correlated with trans-activation. For instance, with $\mathrm{M} 9$ (Fig. 3B, lanes 5 and 6), M10 (Fig. 3A, lanes 1 and 2), and M11 (Fig. 3B, lanes 7 and 8 , which could not be trans-activated, the levels of full-length transcripts were not increased in the presence of tat. With the exception of M5 (Fig. 3B, lanes 1 and 2), M6 (Fig. 3B, lanes 3 and 4), and MC2 (Fig. 3A, lanes 7 and 8 ), short transcripts were detected in the absence of tat with both wild-type and mutant constructions. In $\mathrm{MC} 2$, small RNA species of $\sim 21$ nucleotides near the bottom of the gel probably correspond to a partial digestion of the probe (Fig. 3A, lanes 7 and 8); additional GC base-pairing in $\mathrm{MC} 2$ increased the predicted stability $(\Delta \mathrm{G}=-42.4 \mathrm{kcal} / \mathrm{mole})$ of the lower stem, which might have made hybridization with the probe more difficult. In M5 and M6, the loss of base-pairing in the lower stem probably allowed for degradation of prematurely terminated transcripts (Fig. 1A). The requirement for an intact base of the stem for the recovery of the short transcripts was confirmed with studies on $3^{\prime}$ deletions and $5^{\prime}$ insertions (see below). Results for M13 hybridized with long (100 nucleotides) and truncated (60 nucleotides) probes confirmed that prematurely terminated transcripts originate from the $5^{\prime}$ end of mutant (Fig. 3B, lanes 9-12), as was found with wild-type transcripts (Kao et al. 1987). In Figure 3, protected full-length RNA species from $\mathrm{MCl}$ (Fig. 3A, lanes 5 and 6), $\mathrm{MC2}$
(Fig. 3A, lanes 7 and 8), and M11 (Fig. 3B, lanes 7 and 8) migrated more slowly in the gel, probably as a result of nucleotide changes affecting secondary structure. This notion was confirmed when probes identical in length, but containing distinct RNA sequences, migrated differently in denaturing polyacrylamide gels (Fig. 3D).

As mentioned above, the recovery of short transcripts

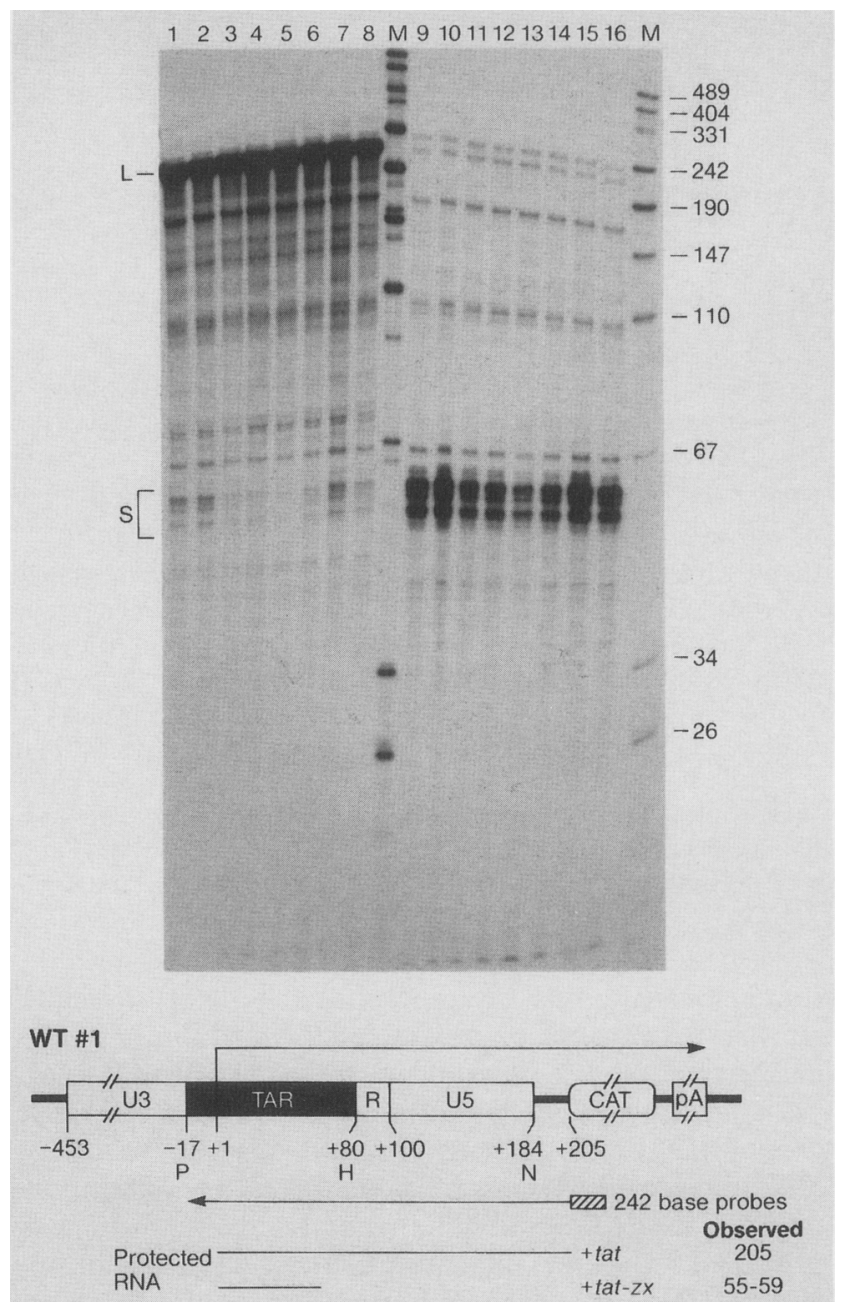

Figure 2. Optimization of hybridization for RNase protection of HIV-1 transcripts. COS-7 cells were cotransfected with pHIV-1CATSV and pSVTAT or pSVTATZX, plasmids containing functional or nonfunctional tat, respectively. (Lanes 1-8) RNA from cells cotransfected with pSVTAT; (lanes 9-16) RNA from cells cotransfected with pSVTATZX. $(L)$ Full-length transcripts; $(S)$ prematurely terminated transcripts. The marker lane $(M)$ contains $M s p I$-digested, end-labeled pUC19 fragments whose sizes are given in base pairs at right. Using $400 \mathrm{~mm}$ $\mathrm{NaCl}$, the temperatures of hybridization were: $35^{\circ} \mathrm{C}$ (lanes 1,9 ); $37^{\circ} \mathrm{C}$ (lanes 2,10$) ; 39^{\circ} \mathrm{C}$ (lanes 3,11$) ; 41^{\circ} \mathrm{C}$ (lanes 4,12$)$; and $43^{\circ} \mathrm{C}$ (lanes 5,13). Maintaining the temperature at $37^{\circ} \mathrm{C}$, the concentration of $\mathrm{NaCl}$ was varied. (Lanes 6,14 ) $300 \mathrm{mM} \mathrm{NaCl}$; (lanes 7,15) $200 \mathrm{~mm} \mathrm{NaCl}$; (lanes 8,16) $100 \mathrm{~mm} \mathrm{NaCl}$. The hybridization solution additionally contained $80 \%$ formamide, $40 \mathrm{mM}$ PIPES (pH 7.0), and 1 mM EDTA. (Bottom) The probe used and the sizes of the protected RNA species. Uppercase letters represent restriction endonuclease sites: (P) PstI; (H) HindIII; (N) NarI. (pA) SV40 polyadenylation sequences. 
Figure 3. (A) RNase protection of clustered mutations in tar. COS-7 cells were cotransfected with pHIV-1CATSV, clustered or compensatory mutations, and pSVTAT or pSVTATZX. (Lanes $1,3,5,7,9$ ) RNA from cells cotransfected with pSVTAT; (lanes 2,4,6,8,10) RNA from cells cotransfected with pSVTATZX. (Lanes 1,2) M10; (lanes 3,4) M13; (lanes 5,6) MC1; (lanes 7,8) MC2; (lanes 9,10) pHIV-1CATSV. ( $L$ and $S$ ) Fulllength and prematurely terminated transcripts, respectively. (Left) The sizes of MspI-digested pUC19 fragments are given in base pairs. RNA from each clustered mutation was annealed with its corresponding RNA probe. The probes were $220 \mathrm{nu}$ cleotides long and extended from ScaI $(\mathrm{S})$ to HindIII $(\mathrm{H})$ sites. The wild-type probe used and the sizes of the protected RNA are shown in $C .(B)$ RNase protection of M5, M6, M9, M11, and M13. (Lanes 1,2) M5; (lanes 3,4) M6; (lanes 5,6) M9; (lanes 7,8) M11; (lanes 9-12) M13. (Lanes 1,3,5,7,9,12) RNA from cells cotransfected with pSVTAT; (lanes 2,4,6,8,10,11) RNA from cells cotransfected with pSVTATZX. RNA from each clustered mutation was annealed with its corresponding RNA probe. The probes for lanes 1-10 were 100 nucleotides long and extended from PvuII $(\mathrm{P})$ to HindIII $(\mathrm{H})$ sites. The probes for lanes 11 and 12 were truncated to 60 nucleotides at $B g I I I(B)$ site. The sizes of the truncated probe and protected RNA are shown in $C .(C)$ The probe used and the sizes of the protected RNA species are shown. Uppercase letters represent restriction endonuclease sites: (B) BglII; (H) HindIII; (P) PvuII; (S) ScaI. (pA) SV40 polyadenylation sequences. $(D)$ The migration of radiolabeled RNA probes in denaturing polyacrylamide gels. (Lanes 1-3) 220-nucleotide-long ScaI-HindIII probes to wild-type HIV-1LTR, $\mathrm{MC1}$, and $\mathrm{MC2}$, respectively; (lanes 4-6) 100-nucleotide-long PvuII-HindIII probes to wild-type HIV-1 LTR, MCl, and MC2, respectively.

was dependent on an intact base of the stem-loop. Both full-length and prematurely terminated transcripts were recovered with $\mathrm{D} 1\left(3^{\prime}\right.$ deletion to position +61 in tar; Fig. 4, lanes 3 and 4), which displayed wild-type transactivation. In contrast, no short transcripts were recovered with D2 ( 3 ' deletion to position +45 , Fig. 4, lanes 5 and 6). Thus, stem-loops that are shorter than wild type or contain fewer base pairs at their bases are less stable and therefore more susceptible to degradation by endogenous RNases.

\section{Effect of position of tar on trans-activation by tat}

To determine how the location of tar relative to the cap site influences trans-activation, we examined a series of insertions made in the $5^{\prime}$ end of tar. Previous studies, which placed tar (positions -17 to +80 ) at various sites relative to the HIV-1 LTR and CAT gene sequences, demonstrated that tar functions in a position- and orientation-dependent manner (Peterlin et al. 1986; Muesing et al. 1987). Hauber and Cullen (1988) introduced two insertions between the HIV-1 promoter and the site of initiation of transcription, which changed the cap site and resulted in reduced levels of trans-activation by tat. We introduced insertions at the $5^{\prime}$ end of tar which preserved the native HIV-1 cap site. Insertions of defined lengths (multiples of $11 \mathrm{bp}$ or approximately one helical turn) were introduced at an artificial $\mathrm{XbaI}$ site at position +8 (Fig. $5 \mathrm{~A}$ ), which precedes the functionally important region of tar (Jakobovits et al. 1988 and see

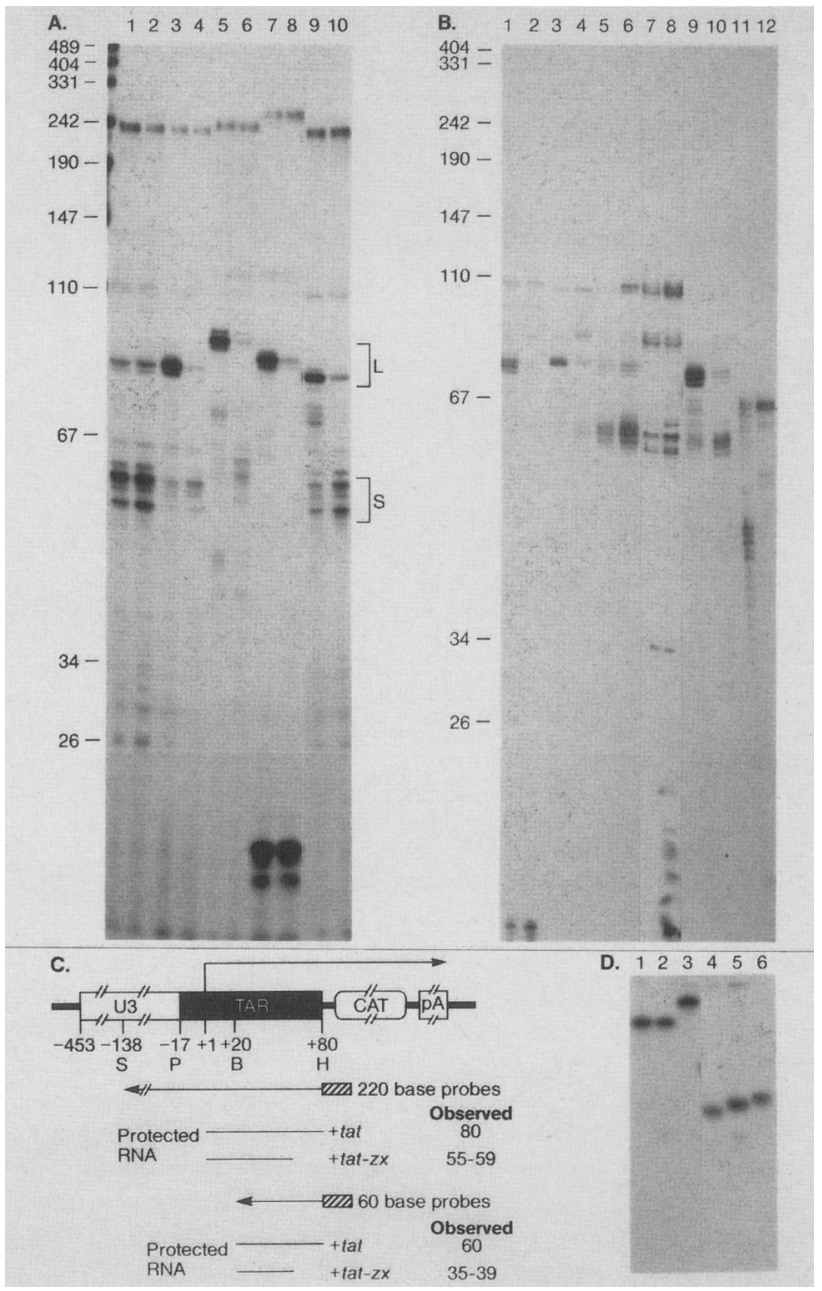

above). We found that the levels of trans-activation were inversely proportional to the lengths of the insertions (Fig. 5B). CAT activities in the absence of tat did not change substantially with these insertions, suggesting that basal transcription was not affected (data not shown). The gradual loss of trans-activation suggests that tat becomes increasingly less able to function as the target sequence is moved distal to the promoter.

To verify that transcripts from $5^{\prime}$ insertions initiate at the HIV-1 cap site and to assay for prematurely terminated transcripts, we analyzed RNA from cells transfected with the largest insertion, p14. The size of fulllength RNA is consistent with initiation of transcription at position +1 (Fig. 5C, lanes 2 and 3). Smaller RNA species of 41-43 nucleotides were also protected. Because pBR322 sequences from positions +3000 to +3042 were used in the construction of pI4, the small protected RNA species could represent hybridization to transcripts derived from the vector and not the stemloop in tar. This was confirmed by hybridization to RNA from COS-7 cells transfected with vector alone (Fig. 5C, lane 1). Prematurely terminated transcripts could not be recovered with pI4 because of the loss of some basepairing in the base of the stem. In summary, the introduction of 88 nucleotides in tar did not change the cap 


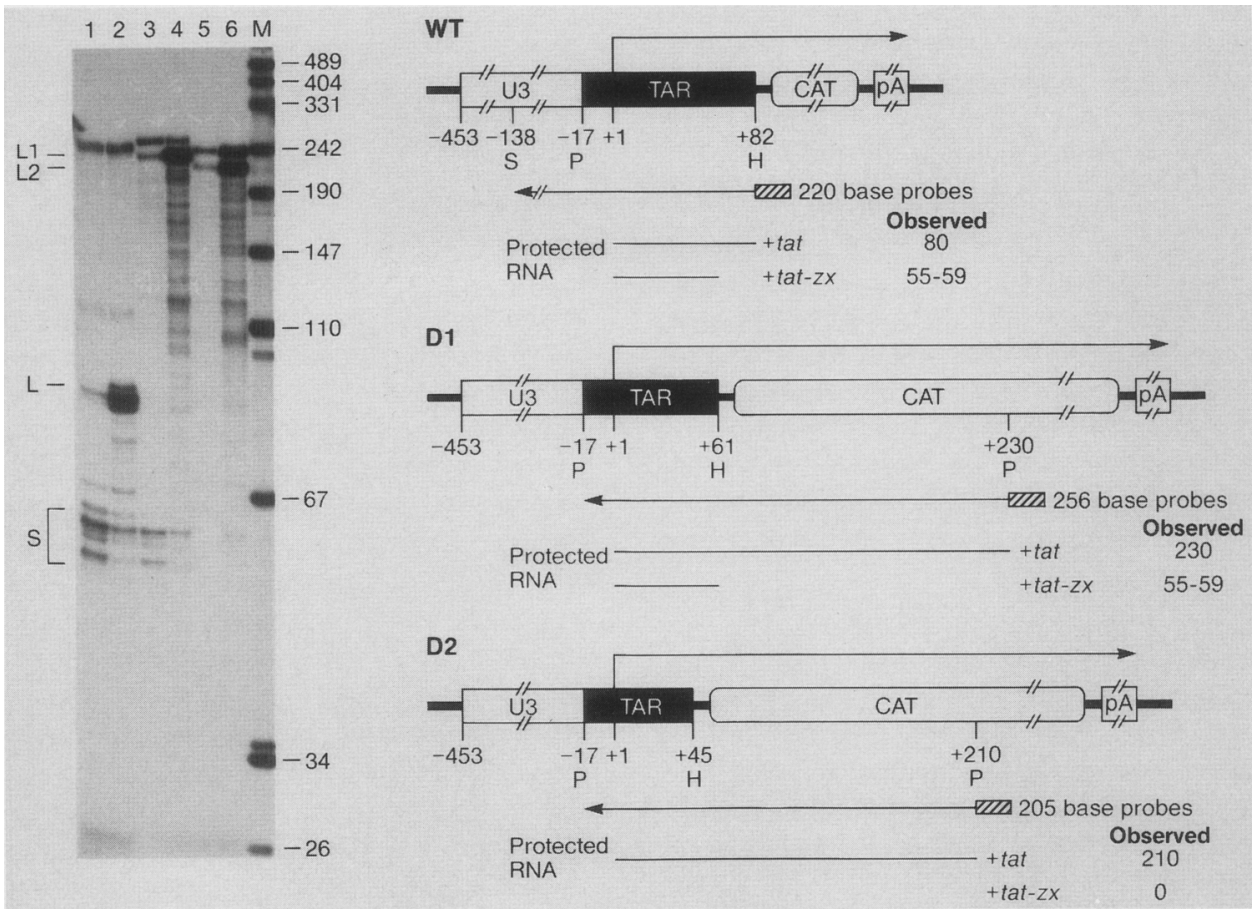

Figure 4. RNase protection of $3^{\prime}$ deletions in tar. COS-7 cells were cotransfected with pHIV-1CATSV or $3^{\prime}$ deletions D1 and D2 with pSVTAT or pSVTATZX. The lanes represent RNA from cells transfected with pHIV-1CATSV (lanes 1 and 2), D1 (lanes 3 and 4 ), and D2 (lanes 5 and 6). (Lanes 1,3,5) RNA from cells cotransfected with pSVTATZX; (lanes 2,4,6) RNA from cells cotransfected with pSVTAT. L, L1, and L2 refer to full-length and S to the prematurely terminated transcripts of wild-type, D1, and D2 protection assays, respectively. $\mathrm{L} 1$ and $\mathrm{L} 2$ are longer by 150 and 130 nucleotides than $\mathrm{L}$, respectively, because the probes for D1 and D2, but not for pHIV-1CATSV, extend into CAT-coding sequences. Lane $M$ contains $M s p I$-digested end-labeled pUC19. The sizes of the DNA fragments are given in base pairs. The probes and the sizes of the protected RNA species are presented diagrammatically to the right of the autoradiogram. (WT) pHIV-1CATSV; (D1) deletion to position +61 ; (D2) deletion to position +45 . Uppercase letters represent restriction endonuclease sites: (S) ScaI; (P) PvuII $(\mathrm{H})$ HindIII. (pA) SV40 termination and polyadenylation sequences.

site nor reduce basal levels of expression, but resulted in 5.5 -fold reduced trans-activation.

\section{Prematurely terminated transcripts in HIV-2}

Although the genomes of HIV-1 and HIV-2 show only $\sim 50 \%$ sequence identity (Emerman et al. 1987; Guyader et al. 1987), the sequences of their predicted stem-loops are very similar, especially in the region that is critical for trans-activation in HIV-1 (Fig. 1B; cf. nucleotides 14-45 in HIV-1 and 21-49 in HIV-2). Because CAT assays from COS-7 cells cotransfected with pSVTAT and pHIV-1CATSV or pHIV-2CATSV yielded comparable levels of trans-activation (Table 1), we looked for prematurely terminated transcripts in COS-7 cells transfected with pHIV-2CATSV. The hybridization temperature was varied to obtain more efficient recovery of short and full-length HIV-2 transcripts (Fig. 6). In the presence of tat, full-length transcripts were observed (Fig. 6; lanes 5-8). However, in the absence of tat, the levels of fulllength transcripts were reduced, and increased levels of a shorter RNA were observed (Fig. 6; lanes 1-4). This short RNA extends to position +123 , which corresponds to the base of the predicted stem-loop in HIV-2 (Fig. 1B). Discrete bands appearing below the full-length bands apparently derive from partial protection of fulllength RNA due to incomplete hybridization with the probe. Thus, in both HIV-1 and HIV-2, short transcripts corresponding to the predicted stem-loops are recovered in the absence of tat, whereas full-length transcripts are observed in the presence of tat.

\section{Discussion}

In this study we defined functionally important regions of HIV-1 tar, the relevance of secondary structure in the stem and primary sequence in the loop of the stem-loop in tar for trans-activation, and the dependence of tar on its distance from the HIV-1 cap site. Furthermore, we correlated the stability of the secondary structure in tar with trans-activation and the recovery of prematurely terminated transcripts. These data extend and support our previous observations that tat functions to elongate nascent transcripts through the HIV-1 LTR (Kao et al. 1987).

CAT assays of $3^{\prime}$ deletions and clustered mutations in tar demonstrated that sequences from positions +14 to +45 are most important for trans-activation by tat. Our borders of functional tar agree with those from positions +19 to +42 mapped by Jakobovits et al. (1988). The sizes of clustered mutations or the actual nucleotides mutated may account for the small differences in the borders between our studies. It should be noted that transfections with nonreplicating (data not shown) and 
replicating plasmids yielded equivalent results.

Although studies of clustered mutations alone revealed the borders of tar required for trans-activation, analysis of clustered and compensatory mutations distinguished between the contributions of primary sequence and secondary structure of the predicted stemloop in tar. Because the mutations in M10 are in the loop exclusively and do not affect the stem, the absence of trans-activation and full-length transcripts in M10
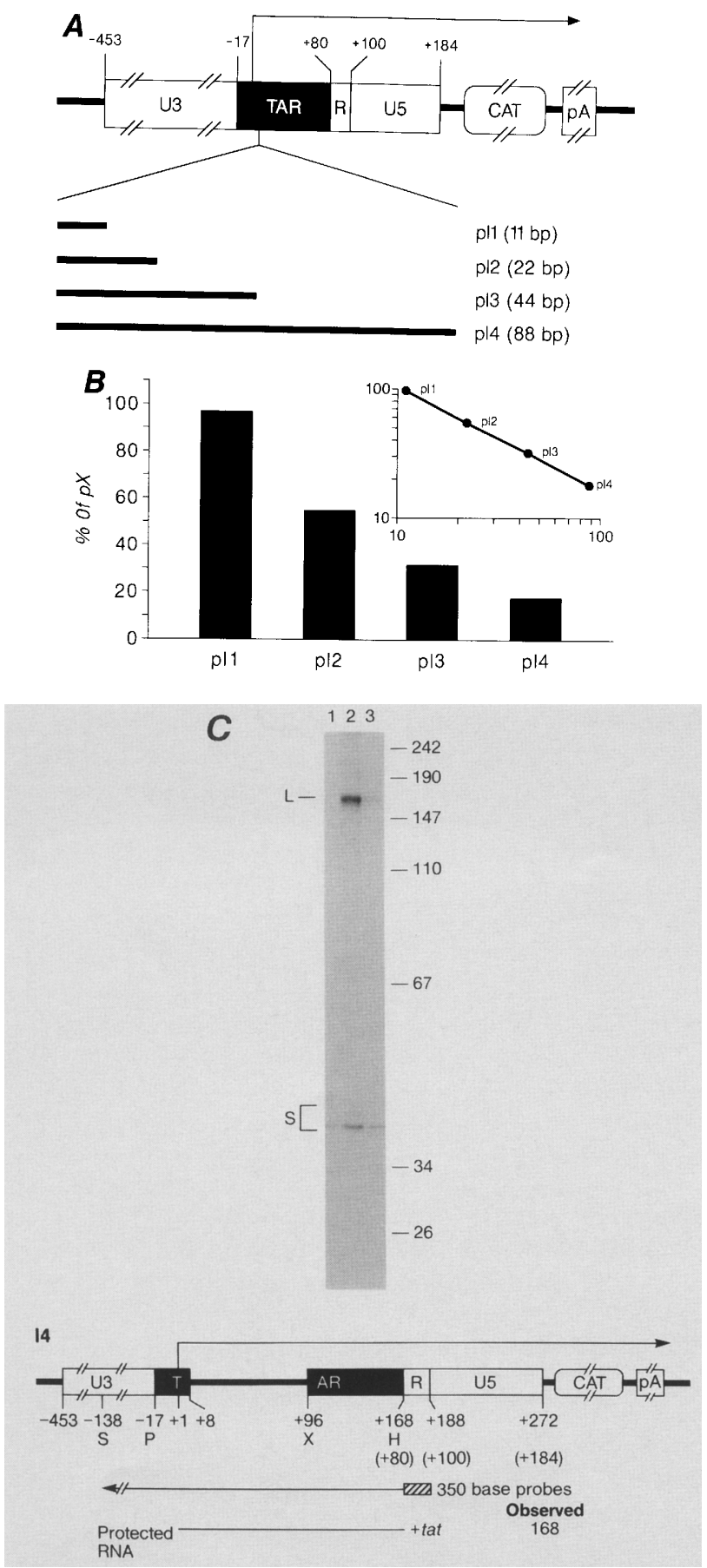

demonstrate that the primary sequence of the loop is essential. This notion was confirmed by a study of single point mutations in the loop of HIV-1 (Feng and Holland 1988). MC1, composed of two clusters of mutations in the mid-stem, each of which decreased trans-activation greatly (i.e., M8 and M12), restored base-pairing and trans-activation. $\mathrm{MCl}$ did not restore trans-activation completely to wild-type levels, probably because of less than wild-type stability (three GC and two AU base pairs were replaced by five AU base pairs). MC2 demonstrated that the base of the stem still contributes slightly to trans-activation. Because the secondary structure at the very top of the stem is required absolutely for transactivation (Feng and Holland 1988), it appears that the relative contribution of the stem to trans-activation decreases with the distance from the loop.

A comparison of tar from HIV-1 and HIV-2 supports our conclusion on the relative contributions of primary sequence and secondary structure of the predicted stem-loop to trans-activation. We compared sequences from positions +1 to +57 in HIV- 1 to those from positions +1 to +123 in HIV-2 because these sequences correspond to those in the prematurely terminated transcripts. tar of HIV-2 is composed of sequences that not only duplicate the upper stem-loop of tar from HIV-1 (stem-loop I), but also may contain two shorter stemloops (stem-loops II and III) on the $3^{\prime}$ side of the main stem. The sequences CUGGG (Fig. 1B) in the loop are conserved between HIV-1 and HIV-2 (loops I and II). Deletion analysis demonstrated that predicted stem-loops I and II of HIV-2 are required for trans-activation (Emerman et al. 1987; Jakobovits et al. 1988). Between these viruses, the stems most proximal to the conserved loops contain insertions, substitutions, and inversions of nucleotides. Despite variability in sequence, the predicted stability of this portion of the stem is conserved, and the levels of trans-activation are comparable. This analysis supports the notion that primary sequence in the loop and secondary structure in the stem of the pre-

Figure 5. (A) Structure of the four insertions, pI1-pI4, and the parent construction, $\mathrm{pX}$. The insertions in tar (positions -17 to +80 ) at the $X b a$ I site (position +8 ) in $\mathrm{pX}$ are shown below the triangle. The name of the plasmid and the length of the inserted DNA are shown to the right of each insertion. $(B)$ The percent trans-activation of $\mathrm{pX}$ for each insertion is presented. The data shown are from a single transfection performed in duplicate or triplicate. The same pattern was observed with the analysis of three other independent transfections. (Insert) A log-log plot of the percent trans-activation of insertion mutants compared with that of $\mathrm{pX}$ versus the length of the insertion. $(C)$ RNase protection of pI4 transfections. (Lane 1) RNA from COS-7 cells transfected with pSVTAT; (lanes 2,3) RNA from cells cotransfected with pI4 and pSVTAT and pI4 and pSVTATZX, respectively. (Right) The sizes of MspI-digested end-labeled pUC19 fragments are given in base pairs. (Bottom) The probe used and the sizes of the protected RNA. ( $L$ and $S$ ) Full-length HIV and short RNA species that result from protection of vector transcripts, respectively. Uppercase letters represent restriction endonuclease sites: (S) ScaI; (P) PstI; (X) XbaI; (H) HindIII. 


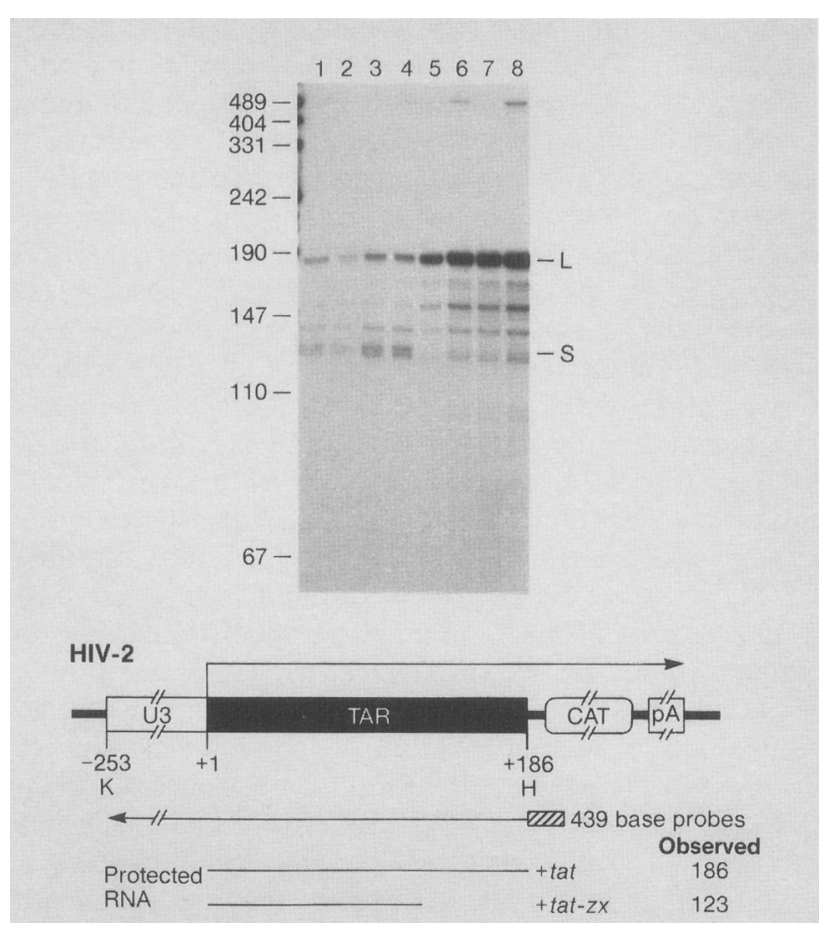

Figure 6. Optimization of hybridization for RNase protection of HIV-2 transcripts. COS-7 cells were cotransfected with pHIV-2CATSV and pSVTAT or pSVTATZX. ( $L$ and $S)$ Fulllength and prematurely terminated transcripts, respectively. (Lanes 1-4) RNA from cells cotransfected with pSVTATZX; (lanes 5-8) RNA from cells cotransfected with pSVTAT. The temperatures of hybridization were $39^{\circ} \mathrm{C}$ (lanes 1,5$) ; 45^{\circ} \mathrm{C}$ (lanes $2,6) ; 50^{\circ} \mathrm{C}$ (lanes 3,7 ); and $55^{\circ} \mathrm{C}$ (lanes 4,8 ). The hybridization solution additionally contained $80 \%$ formamide, 40 mM PIPES (pH 7.0), $1 \mathrm{~mm}$ EDTA, and $200 \mathrm{~mm} \mathrm{NaCl}$. (Bottom) The probe for the HIV-2 LTR and the sizes of the protected RNA species.

dicted stem-loops in tar of HIV-1 and HIV-2 are important for trans-activation.

The detection of prematurely terminated transcripts represents a means to assess the effects of alterations in tar on trans-activation by tat. The secondary structure of these short RNA species allows for their recovery. Thus, mutants that disrupt base pairing at the base of the stem (M5, M6, pI4; Figs. 3 and 5) and deletions $5^{\prime}$ of position +61 (D2 and D3; Fig. 4) yielded no prematurely terminated transcripts. However, even with intact stem-loops, the detection of the RNA can be difficult. Conditions of hybridization must be optimized to demonstrate quantitative recovery of wild-type and mutant RNA species because of competition between inter-and intramolecular base-pairing.

We found that some RNA species migrated with slower or faster mobilities than wild-type full-length or prematurely terminated transcripts (Fig. 3A,B). These bands could represent transcripts that initiated at different sites in the HIV-1 LTR, especially because different cap sites were observed with clustered point mutations from positions -6 to +5 in an in vitro transcription system (Jones et al. 1988). However, in our transient expression assay, two slower migrating transcripts con- tain clustered point mutations $3^{\prime}$ to these sequences (M11 and MC1), and wild-type, MC1, and MC2 RNA probes of identical lengths migrated differently in our denaturing polyacrylamide gels (Fig. 3D). Thus, fulllength $\mathrm{M} 11, \mathrm{MCl}$, and $\mathrm{MC} 2$ transcripts probably represent appropriately initiated RNA possessing different intrinsic mobilities. Low levels of transcription from cryptic promoters in our plasmid vector were also observed (e.g., see Fig. 5C). However, these transcripts that initiate $5^{\prime}$ to the HIV-1 LTR cannot explain the presence of short transcripts in the absence of trans-activation. First, prematurely terminated transcripts are not polyadenylated (data not shown). Second, the levels of prematurely terminated transcripts are much higher than those of read-through transcripts. Third, our previous nuclear run-on experiments revealed that short transcripts initiated and terminated in the HIV-1 LTR (KaO et al. 1987).

The requirement of primary sequence in the loop and secondary structure in the stem of the predicted stemloop in tar for trans-activation by tat is similar to the recognition structures for some RNA-binding proteins. In the replicase gene of bacteriophage R17, the coat protein binds to the loop sequence preceding the coding regions only in the context of a stable stem (Romaniuk et al. 1987). However, tat synthesized in bacteria does not bind specifically to tar RNA or DNA (Frankel et al. 1988). Because tat shares structural and functional features with bacteriophage $\lambda \mathrm{N}$ antiterminator (Franklin and Bennett 1979), which also does not bind to its N-utilization (nut) site, but does bind to a transcription complex that pauses at the nut site (Barik et al. 1987), it is possible that tat will bind only to its target sequence in the presence of RNA polymerase II and associated proteins. In a further analogy with HIV, the nut site forms an RNA stem-loop, and a single nucleotide substitution in the loop abolishes antitermination by $\mathrm{N}$ (Rosenberg et al. 1978; Salstrom and Szybalski 1978; Das and Wolska 1984).

If tat functions through an antitermination mechanism, then one would predict that removal of the termination site would result in constitutively high levels of expression. Although our clustered point mutations in the upper half of the stem-loop in tar and 3 ' deletions to positions +20 and +8 in tar yielded higher basal CAT activities, they did not approach the levels of expression observed with the wild-type HIV-1 LTR after trans-activation by tat. Because we have shown previously that tar-containing RNA is extremely stable (Peterlin et al. 1988 |, one possibility is that while relieving termination, these alterations in the stem-loops also resulted in decreased RNA stabilities. The reduced stability would affect both full-length and prematurely terminated transcripts (Peterlin et al. 1988). However, equivalent levels of prematurely terminated transcripts were observed with M9-M11, as with wild-type HIV-1 LTR, making reduced RNA stability an unlikely explanation. Because some alterations in tar resulted in an up-phenotype, there must be at least some negative regulation contributed by tar RNA or DNA. Such negative regulation 
could be achieved by a sequence or structure where transcription pauses or terminates. Conversely, tar could load a factor that causes premature termination, i.e., a terminator. However, this negative regulation cannot account for the difference between wild-type basal and trans-activated levels of expression. Thus, other features of HIV-1 LTR must be responsible for premature termination. A strong candidate is the type of transcription complex that is assembled at the HIV-1 TATA-box, especially because only certain heterologous promoters placed 5' to tar lead to trans-activation by tat (Peterlin et al. 1986). One way in which the transcription complex might terminate prematurely is that RNA polymerase II initiates in an unstable conformation. In this model, tat or proteins induced by tat would create a conformational change in the polymerase, allowing for efficient elongation. Alternatively, a terminator could associate with the transcription complex at the HIV promoter and suppress transcriptional elongation actively. In this model, tat would either displace the terminator directly or modify the transcription complex. A prediction of this hypothesis is that wild-type levels of expression can be achieved in the absence of tat by depleting the terminator. This might be accomplished by cotransfections with plasmid DNA that contains promoter elements binding the terminator. Alternatively, this protein could be added to in vitro transcription systems and result in premature termination with template DNA from the HIV-1 LTR.

Finally, insertions at position +8 , which displaced tar by multiples of 11 nucleotides or roughly single helical turns but retained the authentic cap site, led to decreased levels of trans-activation (Fig. 5). Lower levels of trans-activation might have resulted from the displacement of binding sites for transcription factors that have been mapped 3' of the HIV-1 cap site (Dinter et al. 1987; Garcia et al. 1987; Jones et al. 1988), especially because mutations in these binding sites decreased transcriptional efficiencies in an in vitro transcription assay (Jones et al. 1988). However, neither insertions nor cluster mutations in tar led to decreased basal levels of expression in our transient transfection assay. A more likely explanation for our findings is that the stem-loop in tar must be near the cap site to allow for efficient interaction between tat or factors induced by tat and the HIV-1 promoter elements facilitating elongation.

Antitermination of transcription in HIV closely resembles that in some prokaryotic and eukaryotic system (for reviews, see Platt 1986; Roberts 1988; Yanofsky 1988). For example, in bacteriophage $\lambda, N$ and $Q$ antiterminators act at their utilization sites (nut and qut, respectively) to modify their operon-specific transcription complexes, thereby allowing efficient elongation through distal termination sites (Grayhack et al. 1985; Barik et al. 1987). The qut site, like tar, has position and orientation dependency, and $\mathrm{Q}$, like $\mathrm{N}$, requires transcription to pause for efficient loading and/or modification of the transcription complex (Yang et al. 1987). Also, the rapid induction of c-myc (Bentley and Groudine 1986; Nepvu and Marcu 1986), c-myb (Bender et al.
1987), and c-fos (Fort et al. 1987) oncogenes may be a consequence of antitermination. Recently, prematurely terminated transcripts were recovered when the c-myc gene was injected into Xenopus oocytes (Bentley and Groudine 1988). In c-myc and small nuclear (sn) RNA genes, their promoters play important roles in transcription termination (Hernandez et al. 1986; Neuman de Vegvar et al. 1986; Bentley and Groudine 1988; Hernandez and Lucito 1988; Tanaka et al. 1988). Similarly, replacement of the HIV-1 promoter with the SV40 early or thymidine kinase (TK) promoters resulted in greatly reduced levels of trans-activation (Rosen et al. 1985; Peterlin et al. 1986). In addition, transcriptional enhancers can inhibit $3^{\prime}$-end formation in snRNA genes (Hernandez and Lucito 1988). Activation of HIV-1 LTR by phorbol esters or by $\mathrm{T}$ cell activation also leads to increased levels of viral gene expression, perhaps through an analogous suppression of premature termination (Kaufman et al. 1987; Nabel and Baltimore 1987; TongStarksen et al. 1987, 1988; Siekevitz et al. 1987). Finally, stalled transcription complexes at inducible promoters have been observed (Rougvie and Lis 1988). Transcriptional activation of these promoters involves efficient elongation of transcription and not increases in the rates of initiation of transcription. It is possible that in many eukaryotic genes, transcriptional enhancers and promoters function in an analogous fashion.

In summary, these data are compatible with the mechanism of transcriptional elongation by tat through the HIV LTR (Fig. 7). We propose that the stem-loop in tar provides a signal for tat or factors induced by tat to associate with and/or modify the transcription complex, thus facilitating elongation of transcription. In the absence of tat, the transcription complex remains susceptible to premature termination. How the HIV promoter and enhancer elements, as well as host cellular factors, contribute to trans-activation by tat is not yet known. Furthermore, the precise termination site(s) has not been mapped. These questions are perhaps best approached by studying trans-activation by tat in well-defined systems, like in Xenopus oocytes, yeast, and in vitro transcription systems.

\section{Methods}

Plasmid constructions

PHIV-1CATSV, pSVTAT, and pSVTATZX have been described previously in Kao et al. (1987). Clustered mutations in tar (from position -17 to +80 ), which introduced unique restriction sites, were generated in pHIV-1CAT by ligating synthetic oligonucleotides from PvuII (position - 17) to BgIII (position +20 ), from BgIII to SacI (position +38 ) and from SacI to HindIII (position +80 ). The HIV-1 LTR and CAT sequences from these nonreplicating plasmid constructions were then moved into a vector containing SV40 origin of replication (pSV-T4, P. Luciw, unpubl.). Nonreplicating and replicating plasmid constructions were transfected into COS-7 cells. Replicating plasmids were cotransfected with pSVTAT or pSVTATZX. Nonreplicating plasmids were cotransfected with tat transcribed from the RSV LTR or with pUC19. D1, D2 and D3 were made by digesting pHIV-1CAT with SacI and HindIII, followed by replacement 
Selby et al.

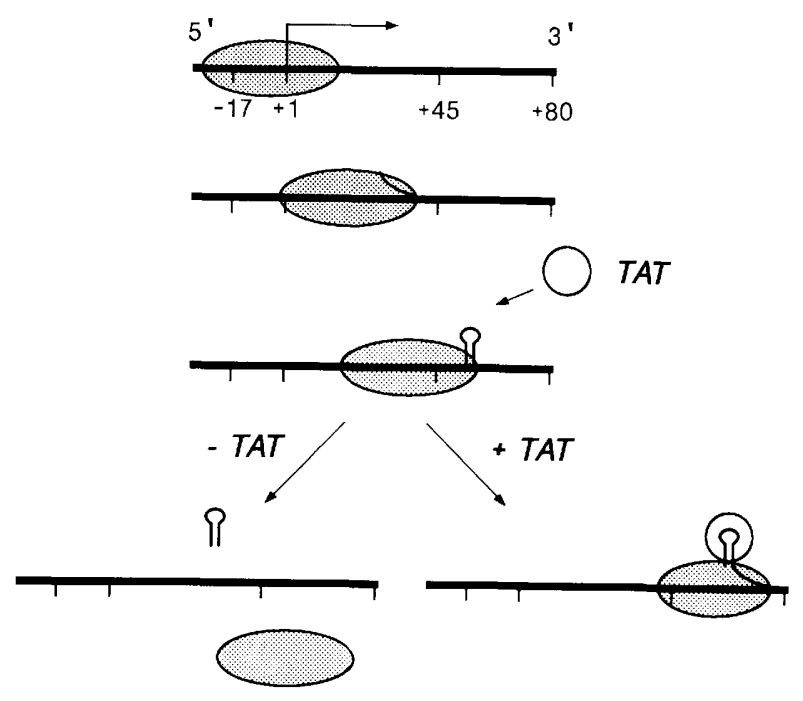

Figure 7. Model for trans-activation by tat. HIV transcriptional enhancer and promoter factors assemble the transcription complex at the site of initiation of transcription. Transcription begins and nascent transcripts are made. By position +57 , tar secondary structure is formed and the stem-loop becomes accessible to tat or factors induced by tat. In the absence of tat, the transcription complex and the nascent RNA fall off the template. Prematurely terminated RNA is stable and can be recovered in the cytoplasm. In the presence of tat, the transcription complex is stabilized, and transcription elongates beyond the stem-loop. Whether tat (or tat-induced factors) binds to RNA and/or the transcription complex and whether tat remains associated or just modifies the transcription complex must be determined.

with synthetic oligonucleotides that resulted in $3^{\prime}$ deletions to positions +61 , +45 , or +42 . To construct deletions D4 and D5, pHIV-1 CATSV, and plasmid X (pX) (see below), respectively, were digested with HindIII and BgIII and XbaI, bluntended, and religated. These constructions were subcloned into the pSV-T4 vector. To construct $5^{\prime}$ insertions, $\mathrm{pX}$ was made by replacing sequences from SphI (position - 10) to BgIII sites in M1 with synthetic oligonucleotides containing changed nucleotides at positions $+6,+7$, and +8 , which created an $X b a I$ site. Into this $X b a$ I site were cloned synthetic oligonucleotides of $88 \mathrm{bp}$ that regenerated only the $3^{\prime} \mathrm{XbaI}$ site and additionally contained SmaI, ClaI, and MluI restriction sites. This plasmid is called pI4. The sequence of the synthetic oligonucleotide is presented below:

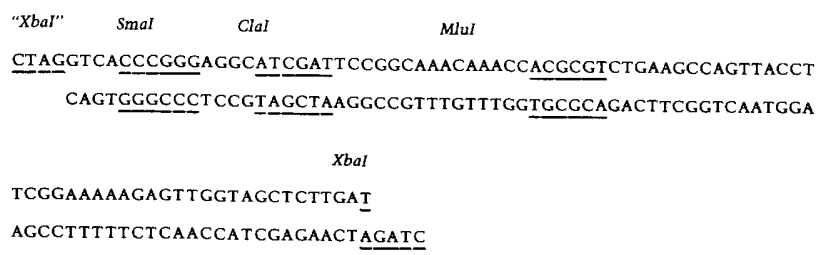

The DNA sequence used between the $\mathrm{ClaI}$ and $\mathrm{XbaI}$ sites, excluding the restriction sites, was derived from positions 3000-3042 in pBR322. As only the $3^{\prime} \mathrm{Xbal}$ site remained, pI4 was digested and self-ligated sequentially with SmaI, CIaI or $M l u I$, and $X b a I$, which resulted in progressively shorter insertions. The sequence of all clustered and compensatory muta- tions, $3^{\prime}$ deletions, and $5^{\prime}$ insertions was verified by doublestranded DNA sequencing.

pHIV-2CAT, a generous gift of M. Emerman and L. Montagnier, was digested with KpnI and HindIII and subcloned into KpnI-HindIII digested pHIV-1CATSV, to generate pHIV-2CATSV.

The RNase protection of HIV-1 was optimized with pLGl (Kao et al. 1987). Other RNase protection assays used pGEM-1/ WT, which was derived by digesting pHIV-1CAT with ScaI (position -138 ) to HindIII (position +80 ) and ligating the HIV-1 LTR containing fragment into pGEM- 1 . The antisense probes for $3^{\prime}$ deletions were made by cloning the HIV-1 containing fragments following digestion by PvuII (from positions -17 to +150 in CAT) into pGEM- 2 to generate pGEM-D1 and pGEMD2. The antisense probe for pI4 was derived by subcloning ScaI (position -138 ) to HindIII (position +168 ) from pI4 into pGEM-1. The antisense probe for HIV-2 was derived by ligating the KpnI (position -253)-HindIII (position +186) fragment into pGEM-2.

\section{Transient transfection assays}

COS-7 cells in 10-cm dishes were transfected with 5-10 $\mu \mathrm{g}$ of supercoiled plasmid DNA as described previously (Kao et al. 1987). All transfections were done with the designated plasmid construction and either pSVTAT or pSVTATZX. Cells were harvested for CAT assays as described (Kao et al. 1987; Neumann et al. 1987). The CAT assay data represent the average values of at least two independent transfections performed in duplicate or triplicate. RNA for RNase protection experiments was prepared from the cytoplasmic fractions of transfected cells (Maniatis et al. 1982).

\section{RNase protection assays}

Cytoplasmic RNA (2-2.5 $\mu \mathrm{g})$ was assayed. The assays were done as outlined (Kao et al. 1987), except that the concentration of $\mathrm{NaCl}$ was reduced from 400 to $200 \mathrm{~mm}$. The hybridization solution additionally contained $80 \%$ formamide, $40 \mathrm{~mm}$ PIPES (pH 7.0), and $1 \mathrm{mM}$ EDTA. Unless stated otherwise, all annealings were conducted at $37^{\circ} \mathrm{C}$. One half of the samples were electrophoresed in $11 \%$ polacrylamide-urea sequencing gels, together with MspI-digested and end-labeled pUC19 DNA fragment (Maniatis et al. 1982).

\section{Acknowledgments}

We are grateful to Katherine Frederick for expert technical assistance and Michael Armanini for preparation of the manuscript. We thank Angelica Medina-Selby, Katherine Jones, Shaw-Yi Kao, Caroline Kane, Peter Kushner, Sandra Tong, and Ben Yen for helpful discussions and Michael Emerman for the gift of pHIV-2CAT. B.M.P. is an assistant investigator in the Howard Hughes Medical Institute. This work was supported, in part, by a grants to B.M.P. from the California Universitywide Task Force on AIDS, American Foundation for AIDS Research (AmFAR), and the National Institutes of Health. P.A.L. is the recipient of an investigator award (K870017) from the California Universitywide Aids Task Force on AIDS and by an NIH grant (AI25109).

\section{References}

Arya, S.K., C. Guo, S.F. Josephs, and F. Wong-Staal. 1985. Trans-activator gene of human T-lymphotropic virus type III (HTLV-III). Science 229: 69-73. 
Barik, S., B. Ghosh, W. Whalen, D. Lazinski, and A. Das. 1987. An antitermination protein engages the elongating transcription apparatus at a promoter-proximal recognition site. Cell 50: 885-899.

Bender, T.P., C.B. Thompson, and W.M. Kuehl. 1987. Differential expression of c-myb mRNA in murine B lymphomas by a block to transcription elongation. Science 237: 14731476.

Bentley, D.L. and M. Groudine. 1986. A block to elongation is largely responsible for decreased transcription of $\mathrm{c}-\mathrm{myc}$ in differentiated HL60 cells. Nature 321: 702-706.

- 1988. Sequence requirements for premature termination of transcription in the human c-myc gene. Cell 53: $245-256$.

Chen, I.S.Y. 1986. Regulation of AIDS virus expression. Cell 47: 1-2.

Clavell, F., D. Guetard, F. Brun-Vezinet, S. Chamaret, M.A. Rey, M.O. Santos-Ferreira, A.G. Laurent, C. Dauget, C. Katlama, C. Rouzioux, D. Klatzmann, L. Champalimaud, and L. Montagnier. 1986. Isolation of a new human retrovirus from West African patients with AIDS. Science 233: 343-346.

Cullen, B.R. 1986. Trans-activation of human immunodeficiency virus occurs via a bimodal mechanism. Cell 46: $973-$ 982.

Das, A. and K. Wolska. 1984. Transcription antitermination in vitro by lambda $\mathrm{N}$ gene product: Requirement for a phage nut site and the products of host nusA, nusB, and nusE genes. Cell 38: 165-173.

Dayton, A.I., J.G. Sodroski, C.A. Rosen, W.C. Goh, and W.A. Haseltine. 1986. The trans-activator gene of the human $\mathrm{T}$ cell lymphotropic virus type III is required for replication. Cell 44: 941-947.

Dinter, H., R. Chiu, M. Imagawa, M. Karin, and A. Jones. 1987. In vitro activation of the HIV-1 enhancer in extracts from cells treated with a phorbol ester tumor promoter. EMBO J. 6(13): $4067-4071$.

Emerman, M., M. Guyader, L. Montagnier, D. Baltimore, and M.A. Muesing. 1987. The specificity of the human immunodeficiency virus type 2 trans-activator is different from that of human immunodeficiency virus type 1. EMBO $I$. 6(12): $3755-3760$.

Fauci, A.S. 1988. The human immunodeficiency virus infectivity and mechanisms of pathogenesis. Science 239: 617622.

Feinberg, M.B., R.F. Jarrett, A. Aldovini, R.C. Gallo, and F. Wong-Staal. 1986. HTLV-III expression and production involve complex regulation at the levels of splicing and translation of viral RNA. Cell 46: 807-817.

Feng, S. and E.C. Holland. 1988. HIV-1 tat trans-activation requires the loop sequence within tar. Nature 334: 165-167.

Fisher, A.G., M.B. Feinberg, S.F. Josephs, M.E. Harper, L.M. Marselle, G. Reyes, M.A. Gonda, A. Aldovini, C. Debouk, R.C. Gallo, and F. Wong-Staal. 1986. The trans-activator gene of HTLV-III is essential for virus replication. Nature 320: $367-371$.

Fort, P., J. Rech, A. Vie, M. Picchaczk, A. Bonnicu, P. Jeanteur, and J. Blanchard. 1987. Regulation of c-fos gene expression in hamster fibroblasts: Initiation and elongation of transcription and mRNA degradation. Nucleic Acids Res. 15(14): $5657-5667$.

Frankel, A.D., D.S. Bredt, and C.O. Pabo. 1988. Tat protein from human immunodeficiency virus forms a metal-linked dimer. Science 240: 70-73.

Franklin, N.C. and G.N. Bennett. 1979. The N protein of bacteriophage lambda, defined by its DNA sequence, is highly basic. Gene 8: 107-115.
Garcia, J.A., F.K. Wu, R. Mitsuyasu, and R.B. Gaynor. 1987. Interactions of cellular proteins involved in the transcriptional regulation of the human immunodeficiency virus. $E M B O J$. 6: $3761-3770$.

Gluzman, Y. 1981. SV40-transformed simian cells support the replication of early SV40 mutants. Cell 23: 175-182.

Gorman, C.M., L.F. Moffat, and B.H. Howard. 1982. Recombinant genomes which express chloramphenicol acetyltransferase in mammalian cells. Mol. Cell. Biol. 2: 1044-1051.

Grayhack, E.J., Z. Yang, L.F. Lau, and J.W. Roberts. 1985. Phage lambda gene $Q$ antiterminator recognizes RNA polymerase near the promoter and accelerates it through a pause site. Cell 42: 259-269.

Guyader, M., M. Emerman, P. Sonigo, F. Clavel, L. Montagnier, and M. Alizon. 1987. Genome organization and transactivation of the human immunodeficiency virus types 2 . Nature 326: $662-669$.

Hauber, J. and B.R. Cullen. 1988. Mutational analysis of the trans-activation-responsive region of the human immunodeficiency virus type I long terminal repeat. J. Virol. 62: 673679.

Hauber, J., A Perkins, E.P. Heimer, and B.R. Cullen. 1987. Trans-activation of human immunodeficiency virus gene expression is mediated by nuclear events. Proc. Natl. Acad. Sci. 84: 6364-6368.

Hernandez, N. and R. Lucito. 1988. Elements required for transcription initiation of the human $\mathrm{U} 2$ snRNA gene coincide with elements required for snRNA 3 ' end formation. EMBO I. 7: 3125-3134

Hernandez, N. and A.M. Weiner. 1986. Formation of the $3^{\prime}$ end of U1 snRNA requires compatible snRNA promoter elements. Cell 47: 249-258.

Ho, D.D., R.J. Pomerantz, and J.C. Kaplan. 1987. Pathogenesis of infection with human immunodeficiency virus. N. Engl. J. Med. 317: 278-286.

Jakobovits, A., D.H. Smith, E.B. Jakobovits, and D.J. Capon. 1988. A discrete element $3^{\prime}$ of human immunodeficiency virus 1 (HIV-1) and HIV-2 mRNA initiation sites mediates transcriptional activation by an HIV trans-activator. Mol. Cell. Biol. 8: 2555-2561.

Jones, K.A., P.A. Luciw, and N. Duchange. 1988. Structural arrangements of transcription control domains within the $5^{\prime}$ untranslated leader regions of the HIV-1 and HIV-2 promoters. Genes Dev. 2: 1101-1114.

Kao, S.Y., A.F. Calman, P.A. Luciw, and B.M. Peterlin. 1987. Anti-termination of transcription within the long terminal repeat of HIV-1 by tat gene product. Nature 330: 489-493.

Kaufman, J.D., G. Valandra, G. Roderiquez, G. Bushar, C. Giri, and M.A. Norcross. 1987. Phorbol ester enhances human immunodeficiency virus-promoted gene expression and acts on a repeated 10-base pair functional enhancer element. Mol. Cell. Biol. 7: 3759-3766.

Malim, M.H., J. Hauber, F. Fenrick, and B.R. Cullen. 1988. Immunodeficiency virus rev trans-activator modulates the expression of the viral regulatory genes. Nature 335: 181-183.

Maniatis, T., W.F. Fritsch, and J. Sambrook. 1982. Molecular cloning: A laboratory manual. Cold Spring Harbor Laboratory, Cold Spring Harbor, New York.

Muesing, M.A., D.H. Smith, and D.J. Capon. 1987. Regulation of mRNA accumulation by a human immunodeficiency virus trans-activator protein. Cell 48: 691-701.

Muesing, M., D. Smith, C. Cabradilla, C. Benton, L. Lasky, and D. Capon. 1985. Nucleic acid structure and expression of the human AIDS retrovirus. Nature 313: 450-458.

Nabel, G. and D. Baltimore. 1987. An inducible transcription 
factor activates expression of human immunodeficiency virus in T cells. Nature 326: 711-713.

Nepvu, A. and K.B. Marcu. 1986. Intragenic pausing and antisense transcription within the murine c-myc locus. $E M B O J$. 5(11): 2859-2865.

Neuman de Vegvar, H.E., E. Lund, and J.E. Dahlberg. 1986. 3' End formation of Ul snRNA precursors is coupled to transcription from snRNA promoters. Cell 47: 259-266.

Neumann, J.R., C.A. Morency, and K.O. Russian. 1987. A novel rapid assay for chloramphenicol acetyltransferase gene expression. Biotechniques 5(5): 444-448.

Peterlin, B.M., P.A. Luciw, P.J. Barr, and M.D. Walker. 1986. Elevated levels of mRNA can account for the transactivation of human immunodeficiency virus (HIV). Proc. Natl. Acad Sci. 83: 9734-9738.

Peterlin, B.M., A.F. Calman, S.Y. Kao, M.J. Selby, S.E. TongStarksen, and P.A. Luciw. 1988. Activation and trans-activation of HIV-1. In The control of human retrovirus gene expression (ed. B.R. Franza, B.R. Cullen, and F. Wong-Staal), pp. 45-57, Cold Spring Harbor Laboratory, Cold Spring Harbor, New York.

Platt, T. 1986. Transcription termination and the regulation of gene expression. Annu. Rev. Biochem. 55: 339-372.

Ratner, L., W.A. Haseltine, J. Livak, B. Starcich, S.F. Josephs, E.R. Doran, J.A. Rarlaski, E.A. Whitehorn, K. Baumeister, L. Ivanoff, S.R. Petteway Jr., M.L. Pearson, J.A. Lautenberger, T.S. Papas, I. Ghrayeb, N.T. Chang, R.C. Gallo, and F. Wong-Staal. 1985. Complete nucleotide sequence of the AIDS virus, HTLV-III. Nature 313: 277-284.

Rice, A.P. and M.B. Matthews. 1988. Transcriptional but not translational regulation of HIV-1 by the tat gene product Nature 332: $551-553$.

Roberts, J.W. 1988. Phage lambda and the regulation of transcription termination. Cell 52: 5-6.

Romaniuk, P.J., P. Lowary, H. Wu, G. Stormo, and O.C. Uhlenbeck. 1987. RNA binding site of R17 coat protein. Biochemistry 26: 1563-1568.

Rosen, C.A., J.G. Sodroski, and W.A. Haseltine. 1985. The location of cis-acting regulatory sequences in the human $\mathrm{T}$ cell lymphotropic virus type III (HTLV-III/LAV) long terminal repeat. Cell 41: 813-823.

Rosen, C.A., E.F. Terwilliger, A.I. Dayton, J.G. Sodroski, and W.A. Haseltine. 1988. Intragenic cis-acting art gene responsive sequences of the human immunodeficiency virus. Proc. Natl. Acad. Sci. 85: 2071-2075.

Rosen, C.A., J.G. Sodroski, W.C. Goh, A.I. Dayton, J. Lippke, and W.A. Haseltine. 1986. Post-transcriptional regulation accounts for the trans-activation of the human T-lymphotropic virus type III. Nature 319: 555-559.

Rosenberg, M., D. Court, H. Shimatake, C. Brady, and D. Wulff. 1978. Structure and function of an intercistronic regulatory region in bacteriophage lambda. In The operon (ed. J.J. Miller and W.S. Reznikoff), pp. 345-371. Cold Spring Harbor Laboratory, Cold Spring Harbor, New York.

Rougvie, A.E. and J.T. Lis. 1988. The RNA polymerase II molecule at the $5^{\prime}$ end of the uninduced hsp 70 gene of D. melanogaster is transcriptionally engaged. Cell 54: 795-804.

Salstrom, J.S. and W. Szybalski. 1978. Coliphage גnutL: A unique class of mutants defective in the site of gene $\mathrm{N}$ product untilization for antitermination of leftward transcription. J. Mol. Biol. 124: 195-221.

Sanchez-Pescador, R., M.D. Power, P.J. Barry, K.S. Stimer, M.M Stempien, S.L. Brown-Shimer, W.W. Gee, A. Renard, A. Randolph, J.A. Levy, D. Dina, and P.A. Luciw. 1985. Nucleotide sequence and expression of an AIDS-associated retrovirus (ARV-2). Science 227: 484-492.
Siekevitz, M., S.F. Josephs, M. Dukovich, N. Peffer, F. WongStaal, and W.C. Greene. 1987. Activation of the HIV-1 LTR by $\mathrm{T}$ cell mitogens and the trans-activator protein of HTLV-1. Science 238: 1575-1578.

Sodroski, J., R. Patarca, and C. Rosen. 1985. Location of the trans-activation region on the genome of human T-cell lymphotropic virus type III. Science 229: 74-77.

Sodroski, J., W.C. Goh, C. Rosen, A. Dayton, E. Terwilliger, and W. Haseltine. 1986. A second post-transcriptional trans-activator gene required for HTLV-III replication. Nature 321:412-417.

Tanaka, M., U. Grossniklaus, W. Herr, and N. Hernandez. 1988. Activation of the U2 snRNA promoter by the octamer motif defines a new class of RNA polymerase II enhancer elements. Genes Dev. 2: 1764-1778.

Tong-Starksen, S.E., P.A. Luciw, and B.M. Peterlin. 1987 Human immunodeficiency virus long terminal repeat responds to T-cell activation signals. Proc. Natl. Acad. Sci. 84: $6845-6849$.

. 1988. Signalling through $\mathrm{T}$ lymphocyte surface proteins, TCR/CD3 and CD28, activates the HIV-1 long terminal repeat. I. Immunol. 142: 702-707.

Varmus, H. 1988. Regulation of HIV and HTLV gene expression. Genes Dev. 2(9): 1055-1062.

Wain-Hobson, S., P. Sonigo, O. Danos, S. Cole, and M. Alizon. 1985. Nucleotide sequence of the AIDS virus, LAV. Cell 40: $9-17$.

Wright, C.M., B.K. Felber, H. Paskalis, and G.N. Pavlakis. 1986. Expression and characterization of the trans-activator of HTLV-III/LAV virus. Science 234: 988-992.

Yang, X., C.M. Hart, E.J. Grayhack, and J.W. Roberts. 1987. Transcription antitermination by phage $\lambda$ gene $Q$ protein requires a DNA segment spanning the RNA start site. Genes Dev. 1: 217-226.

Yanofsky, C. 1988. Transcription attenuation. I. Biol. Chem. 263(2): 609-612.

Zucker, M. and P. Stiegler. 1981. Optimal computer folding of large RNA sequences using thermodynamics and auxiliary information. Nucleic Acids Res. 9: 133-148. 


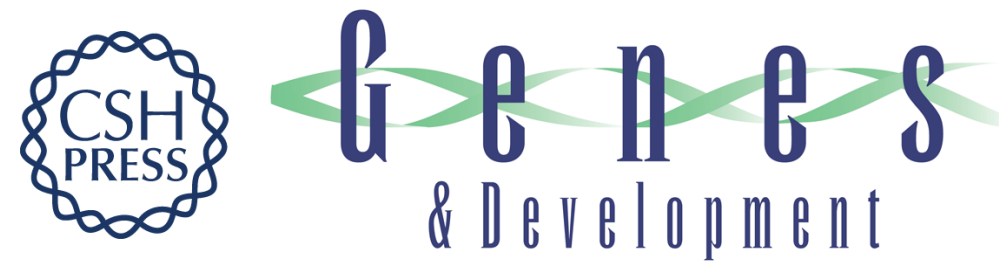

\section{Structure, sequence, and position of the stem-loop in tar determine transcriptional elongation by tat through the HIV-1 long terminal repeat.}

M J Selby, E S Bain, P A Luciw, et al.

Genes Dev. 1989, 3:

Access the most recent version at doi:10.1101/gad.3.4.547

References This article cites 64 articles, 22 of which can be accessed free at: http://genesdev.cshlp.org/content/3/4/547.full.html\#ref-list-1

License

Email Alerting Service

Receive free email alerts when new articles cite this article - sign up in the box at the top right corner of the article or click here.

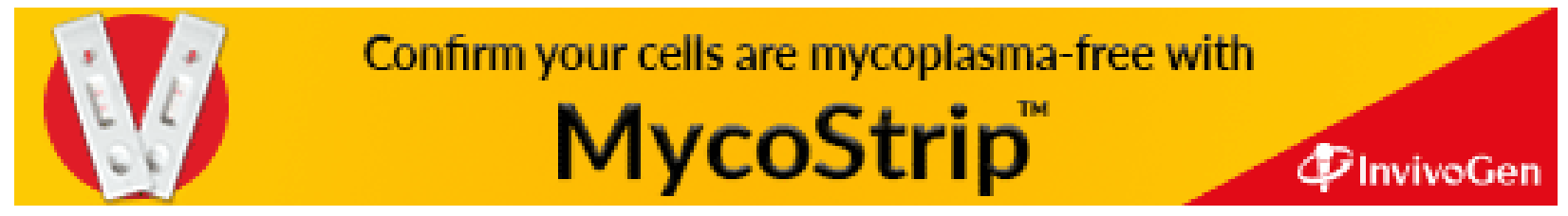

